Notes on the flora of Gardner Island

$$
\text { by C. R. Long: }
$$

Thirty species of vascular plants have been collected and/or recorded from Gardner Island. The majority of the introduced species (designated by an asterisk) were probably brought from the Gilbert Islands in the late $1930^{\prime} \mathrm{s}$ by settlers. Vascular plants were collected by the U. S. Exploring Expedition in 1840 (one sheet of this collection was located in the United States National Herbarium); and, by C. R. Long in October 1964.

\title{
Gramineae
}

Cenchrus echinatus L.*

Long 2467 (UH). The burrgrass forms heavy stands in coral rubble of the abandoned village and is naturalizing along paths of the north and the south portions.

\section{Digitaria pacifica Stapf **}

Long $2476,2504,2515(\mathrm{UH})$. In coral gravel of roadway in village and on the east portion of the southwest island. This species appears to be naturalizing widely over the island.

Eragrostis tenella (Iink.) Beauv.*

Long $2471(\mathrm{UH})$. In coral gravel of the abandoned village and adjacent $\underline{\text { Cocos groves. }}$

Lepturus repens (Forst.) R. Br.

Long 2465, 2472, 2489, 2493, 2508 (UH). Common in sandy soils over the island.

\section{Cyperaceae}

Fimbristylis cymosa R. Br.

Long 2459,2505 (UH). In a well watered depression of coral rubble on the southwest island among dead Cocos. Possibly introduced.

\section{Palmae}

Cocos nucifera I.

Groves occur on the west and south sides the majority of which have been planted in modern times. Between 1938 and 1940, 8,000 coconuts had been planted (Laxton, 1951).

\section{Amaryliidaceae}

Crinum asiaticum $I_{0} *$

Long 2525 (UH). Ornamental near abandoned huts in village.

\section{Urticaceae}

Fleurya ruderalis (Forst. f.) Gaud. ex Wedd.

Long 2502 (UH). On coralline hardpan, north side, under shade of 
Boerhavia repens L.

Long $2454,2460,2461,2462,2463,2497,2518,2519,2521,2522$ (UH). Common over the island with flowers white to lavender. Some of the specimens were dark with heavy concentrations of anthocyanins in the stems and leaves.

Pisonia grandis $\mathrm{R}$. Br.

Long 2454,2456 (UH). Trees to $5 \mathrm{~m}$. distributed along the north side. Laxton (1951) indicates that this forest type was of much greater extent. Many of the trees on the north side east of the northwest hook are dry and sprouting from lower branches only. An aerial photograph of the island in 1939 shows the extent of the Pisonia forests on the northwest end (Weins, 1963).

\section{Aizoaceae}

Sesuvium portulacastrum var. griseum Deg. and Fosb.

Long 2452, 2511 (UH). Mat on the west side at the lagoon edge. This species is important in land building along the lagoon.

\section{Portulacaceae}

Portulaca Iutea Sol.

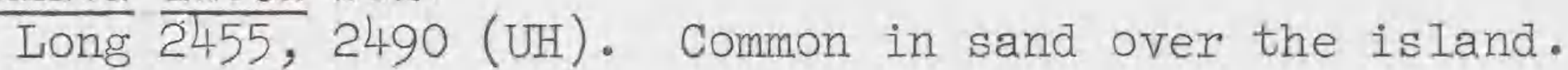

Portulaca oleracea L.*

Long 2499 (UH). In gravel of the village, uncommon.

Portulaca samoensis $v$. Poelln.*

Long 2470,2524 (UH). In village under Cocos.

\section{Zygophyllaceae}

Tribulus cistoides I. common.

Long $2496(\mathrm{UH})$. Coralline ledge near the lagoon north side, un-

\section{Euphorbiaceae}

Euphorbia cyathophora Murr.*

Long 2466 (UH). In coral gravel of village. Ornamental.

$\frac{\text { Euphorbia }}{\text { Long }} \frac{\text { hirta }}{2509}$ (UH)* . Scattered in the village area.

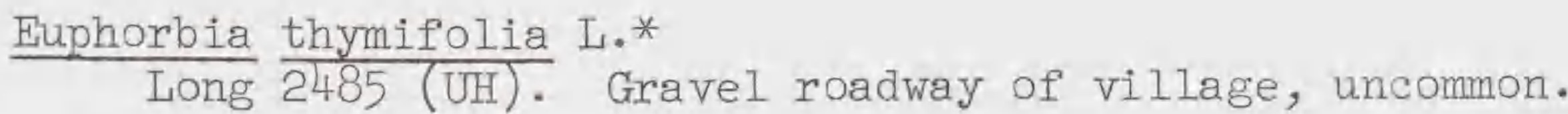

Pedilanthus tithymaloides (I.) Poit.*

Long 2506 (UH). Ornamental found in village.

Phyllanthus amarus Schum. and Thom.*

Long 247 la., 2500 (UH). In shade of Cocos, village. 
Triumfetta procumbens Forst. $f$.

Long $2487,2514(\mathrm{UH})$. East end of is land in coral rubble and under Cocos grove southwest side.

Malvaceae

Sida fallax Walp.

Long 2457, 2491, 2520 (UH). Common in open areas. Many plants

were seen to $1.2 \mathrm{~m}$. high but upper branches were bare.

Caricaceae

Carica papaya L.*

Long $2474(\mathrm{UH})$. Formerly cultivated in the village.

Combretaceae

Terminalia catappa L.*

Long $2494(\mathrm{UH})$. Tree $4 \mathrm{~m}$. high, north shore of lagoon, west side.

Convolvalaceae

Ipomoea tuba (Schlecht.) Don.

Long 2503 (UH). Found on the north and southwest areas rooted

in coralline hardpan, scarce.

Cordia subcordata Lam.

U. S. Exploring Expedition s.n. (USNM). One small dry tree $3 \mathrm{~m}$. high observed on south side in 1964.

Boraginaceae

Tournefortia argentea L. $f$.

Long 2469, $2517(\mathrm{UH})$. Common as fringe on outer beach and lagoon shore.

\section{Solanaceae}

Nicotiana tabacum $I . *$

Long $2510(\overline{\mathrm{UH}})$. In village under Cocos.

Rubiaceae

Morinda citrifolia L.*

Long $2458(\mathrm{UH})$. Formerly cultivated under Cocos groves.

\section{Goodeniaceae}

Scaevola taccada (Gaertn.) Roxb.

Long $2453,2464,2488,2495,2516$ (UH). Common. 
The earliest account of the vegetation of Gardner Island is found in Wilkes (1845) as follows: "The remainder of the reef which forms the island, is white coral sand, about three hundred feet wide, on which there is a vegetation that, unlike that of the other low islands of Polynesia is devoid of low shrubbery." According to this narrative the landing was made on the west side of the is land and mention is made of Cocos forty to fifty feet high. This brief description is clear except for the phrase "devoid of low shrubbery". In 1964 the island was well covered with scrub growth and Cocos. It may be that the scrub fringe was lacking on the west side or that the island was swept by a storm previous to the visit of the Vincennes. According to Ellis (1936) Cocos were planted on the island in the $1880^{\prime} \mathrm{s}$. Bryan (1942) mentions the presence of Pisonia, Cordia, Tournefortia and Cocos. During the $1930^{\circ} \mathrm{s}$ a plan was devised and implemented for the colonization of three islands in the Phoenix Group - Hull, Sydney and Gardner. This operation has been described by Maude (1952) and Laxton (1951). Maude mentions the presence of the following genera: Tournefortia, Scaevola, Morinda, Pisonia, Cordia, Lepturus, Sida and Sesuvium. In this report the soils of Gardner Island are compared to "the peat bogs of Washington Island" and mention is made of the use of Sesuvium as an emergency food. Reference is also made to giant buka trees(Pisonia). Laxton states that when Maude surveyed Gardner Island in 1937 "the great buka trees were everywhere dominant and there were only a few hundred cocoanuts." This reporter goes on to mention that between 1938 and 1940, 8,000 Cocos had been planted, babai pits had been constructed for the coarse taro (Alocasia indica) brought from the Gilbert Islands and the following genera are enumerated: Cenchrus echinatus, Tournefortia, Cordia, Scaevola, and Sida. At the east end the buka trees rise "sixty feet" and on the northwest side.".fluted trunks of fifty feet high buka trees stand pillared, excluding undergrowth." Laxton also remarks: "While working on this area (NW side) we drove a twelve-foot road through the thick buka jungle, bringing down several sixty-foot giants,...". The changes made in the vegetation of Gardner Island and the later failure of the settlement scheme points up the importance of ecological studies on Pacific atolls. It is difficult to understand how the brief (three day) visit of Maude could possibly justify the contention that Gardner Island might eventually support a population of several hundred Gilbertese.

The results of the settlement scheme were seen in 1964. These consist of an extension of the aboriginal Cocos forests of the northwest side over much of the area on the northwest which formerly supported a more extensive buka forest and over the southwest island. Approximately one-quarter of the land east of the channel on the south side has Cocos and several trees are seen on the southeast end. A wide band of Tournefortia and Scaevola was left on the seaward side of the south groves, possibly as a protection for the groves. Decapitated Cocos trees and dead stumps were seen on the south side as well as living trees with yellowed fronds. Few of the trees bore nuts and these were very small. No seedlings were seen. Unlike the vigorous reproduction from dropped seeds on such wet islands as Palmyra and Washington, the Cocos groves of Gardner Island do not appear to be spreading. Former closed groves on the south side are very dry and an undergrowth of Sida and Scaevola is forming. Carefully laid out planting plots in open cleared 
areas are overgrown with Scaevola. Laxton (1951) mentions the large numbers of cocoanut crabs found by the early planters of the $1880^{\prime} \mathrm{s}$ in spite of the fact that the Cocos grove was very limited. These animals appear to be characteristic of islands which do not support Cocos groves (e.g., Birnie) as well as those islands with small stands. Laxton (1951) states that the southeastern island rim has buka trees "reaching no great size" and that at the eastern tip "buka trees rise here sixty feet". No trees of this height were seen in 1964 but dry scattered Pisonia could be seen along the narrow rim on the southeastern side. Cordia is also reported from the eastern tip but this was not verified due to the briefness of our visit.

Gardner Island is characterized by four major plant associations: Cocos, Scaevola - Tournefortia, Pisonia and Lepturus - Sida. The latter three cover the largest portion of the land area. The Pisonia groves are found on the interior mesic sites. In places such as the northwest hook where the land is wide, the Pisonia forms a closed canopy forest of now limited extent. Along the narrower northeast rim the trees are scattered and dry. The Scaevola - Tournefortia forms a fringing vegetation on the north and south sides. The Sida - Lepturus is found on gravel over coralline hardpan in open areas on the north and south sides. Lepturus is often found in pure stands at the edge of the lagoon or scattered under Pisonia trees. It is also common in beach sand near the fringe of Scaevola - Tournefortia. On the north side the latter association forms an open thicketed area almost impenetrable on the seaward side but less thick toward the lagoon. Under some of the Pisonia trees a considerable amount of humus and litter has accumulated over the coral rubble which forms the parent material for soil building. These trees are usually found at the top of a ridge of coral rubble. On the outside there is beach sand and on the inside a slope of coral rubble over coralline hardpan. This hardpan usually extends to the lagoon edge and appears to be $.3 \mathrm{~m}$. above the water at high tide. Unlike Hull Island, the north side of Gardner is unbroken by channels which connect the inner lagoon to the sea. Snall pools on the east end indicate that at one time a channel probably existed at that end of the island. Digitaria was found naturalized on the north side and Ipomoea tuba was found rooted in coralline hardpan and coral rubble along with Fleurya ruderalis and Portulaca lutea.

Among the introductions during the colonization of the island were: Pandanus sp., probably one or more of the scores of cultivars of Pandanus tectorius which have been developed in the Gilbert Islands (see Luomala, 1953); Digitaria pacifica, a grass which is of common introduction in the Line and Phoenix Islands; Eragrostis tenella, a common weed grass; Crinum asiaticum, an ornamental; Portulaca samoensis; Portulaca oleracea; Euphorbia cyathophora, an ornamental; Euphorbia thymifolia; Pedilanthus tithymaloides, an ornamental; Phyl lanthus amarus; Terminalia catappa and Nicotiana tabacum.

Morinda citrifolia was present on the island at the time of Maude's visit in 1937 (Maude, 1952). It is probably an earlier introduction but it is difficult to pinpoint. The most likely possibility was the early copra operation when Cocos were planted since there seems to be no record of a permanent settlement shipping copra. The papaya (Carica papaya) is naturalizing a few local areas in the abandoned village under 
Cocos. On the northwest peninsula north of the channel many trees of Pandanus were found along with excavated taro pits some of which were 1 m. deep. Little humus was found in the bottorn and some of the reedy grasses and Fimbristylis had colonized these relatively mesic sites. Many of the pits were dry.

The following seem to be naturalizing under the Cocos groves: Cenchrus echinatus and Portulaca oleracea. Digitaria is found along the overgrown paths along the north and south sides. On the lagoon side of the southwest island and the northwest hook are wide mud flats. On the southwest these flats are rimmed with Scaevola - Tournefortia and clumps of Lepturus in occasional sandy areas. On the northwest flat is found a mat of Sesuvium. The same type of mat is found at the edge of the small bay which penetrates the northwest peninsula. These filled areas are slowly being built up with reef mud and debris deposited by the flow of water through the west channel from the opening on the south. Sesuvium probably accelerates the process by the addition of humus to the parent material. No Sesuvium is found on the flat on the southwest due to the almost entire covering of that area at high tide. The lagoon near the village has a growth of Turbinaria in the soft mud.

The soils of Gardner Island are very young judging from the weak profiles. Coral sand and rubble are never more than . $5 \mathrm{~m}$. from the surface layers which are usually thin, sandy soils with humus and thin litter layers. The thickest soils were found under the scattered Pisonia trees. The litter layer was thick in such areas but no evidence of the formation of a phosphatized hardpan was seen. The grove on the northwest was not investigated. The Cocos groves had thin soils with dark humus found between and under coral rubble on the surface. Only a few Red-footed Boobies were seen in the Pisonia trees. The east half of both the north and south rims are often bare coralline hardpan. Euphorbia cyathophora was naturalized on the south side in open areas dominated by Boerhavia and Sida. Only one patch of Tribulus was found on a flat, elevated coralline hardpan just above the lagoon on the north side. At the extreme east end of the island is a saline pool surrounded with wave deposited coral gravel covered with Scaevola - Tournefortia scrub. This probably indicates a recent closure of the lagoon on the eastern end. Ipomoea tuba and Triumfetta procumbens are common there. 
Bryan, E. H. Jr. 1942.

American Polynesia and the Hawaiian Chain. 1-253, Honolulu.

Ellis, A. 1936.

Adventuring in Coral Seas. 1-264, Sydney.

Laxton, P. B. 1951.

Nikumaroro. Journal of the Polynesian Society 60: 134-160.

Luomala, K. 1953.

Ethnobotany of the Gilbert Islands. B. P. Bishop Museum Bulletin 213 : $1-129$.

Maude, H. E. 1952.

The Colonization of the Phoenix Islands. Journal of the Polynesian Society 61: 62-89.

Weins, H. J. 1962.

Atoll Environment and Ecology. 1-532, New Haven.

Wilkes, C. 1845 .

Narrative of the United States Exploring Expedition. Volume I-V, Philadelphia. 
Vascular plants recorded from Gardnor Ialend

by C.R. Iong

Graminoao

Conchrus oohinatus I.

C. R. Iong 2467 (UH),

Digitaria pacifica Stapi.

C. R. Lons $2476,(2504,2515$ (UH) 2362,2492

Eragrostis tonolla (Iinls) Beauv.

C. R. Long 247 . .

Ioptumus ropons (Forst.) R: Br.

C. R. Long $2465,2472,24,89,24,93,2508$, (UH).

Wrochusua

Cyperacoao

Fimbristylis cymosa R. Br.

C. R. Lons 2459,2505 (UH).

Amarylizidacoao

Crinum asiaticum I.

C. R. Iong 2525 (UE)。

Urticacoa

Flourya Iudoralis (Forst. $\mathrm{L}_{0}$ ) Gaud. ex Wodd. C. R. Iong 2502 (UH).

Nyctaginacoao

Boerhavia, sp.

'C. R.'Iong' $2454.2460,24.61,24.62,24.63,2497,2518,2519$, 2521, 2522, (UI)。

Pisonia greandis k. Bia

C. R. Ions $2454,2456,2,507$ (UH)。

Aizo20020

Sosuvium portulacastmun vare greisoun Dogo and Fosb.

C. R. Long 24.52, 2511 (UH)。

\footnotetext{
Pomulicos, Iutea Sol.'

Portulacacoas

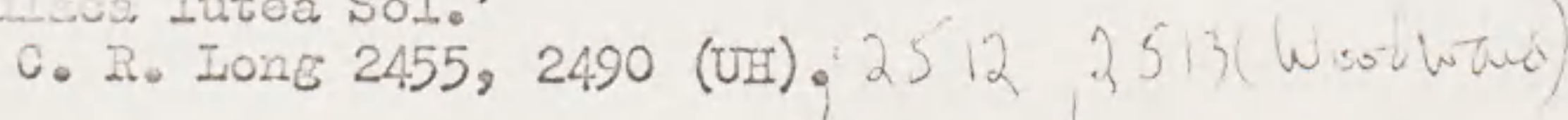


Portulaca oloracoa I:

C. R. Long 2499, 2501 (UI).

Zy sophylaceao

Tribulus cistoidos: I.

C. R. Ions 2496 (UH).

Euphorbiacoao

Euphorbia cyathophora Murr.

C. R. Iong 2466 (UH).

Euphorbia hirta I.

c. R. Long 2509 (UH).

Euphorbia thymifolia I.

C. R. Long 2485 (UH).

Pedilanthus tithymaloidess (I0) Poit.

C. R. Long 2506 (UH).

Phyllanthus amams Schum. and Thom.

C. R. Iong 2500 (UH). $247 \mathrm{HA}$,

Tiliacea

Mriumfotta procumbens Forst. 20

C. R. Iong 2487,2514 (UH).

MaIvacoae

Sida fallax Walp.

C. R. Iong $2457,2491,2520$ (UII).

Caricacoas

Carica papaya I.

C. R. Long 2474 (UH).

Combretaceas

Torminalia catappa I.

C. R. Iong 24.94 (UII).

Convolvulaceao

Ipomooa tuba (SchIecht, Don. 2523

C. R. IOng 2503 (UH)。

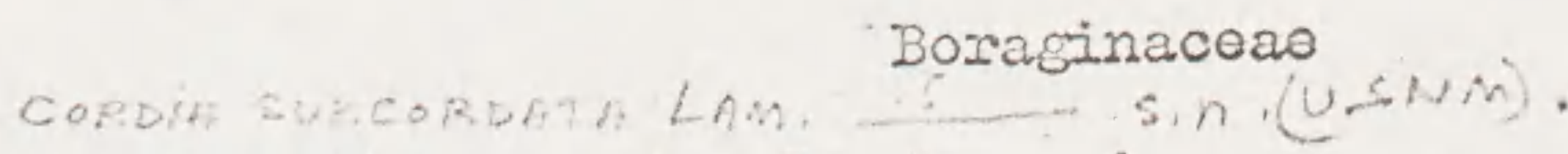

Toumefortia argontea I. $I_{0}$

C. 2. Iong 2469,2517 , (UH).

Wortual 
sic

Gandwer

Solanaceao

Nicotiana tabacum Io

C. R. IOng $2510^{\circ}$ (UH).

Rrubiacoao

Morinda citrifolia I.

C. R. Iong 2458 (UH).

Goodoniacoa

Soavrola taccada (Gaortno) Roxib.'

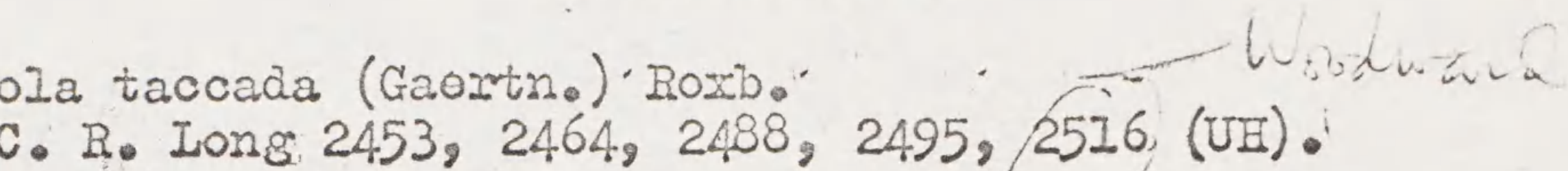

.

Eleusine indica (L) gaert W, 22 Oct. Longt hordwand. it 2468

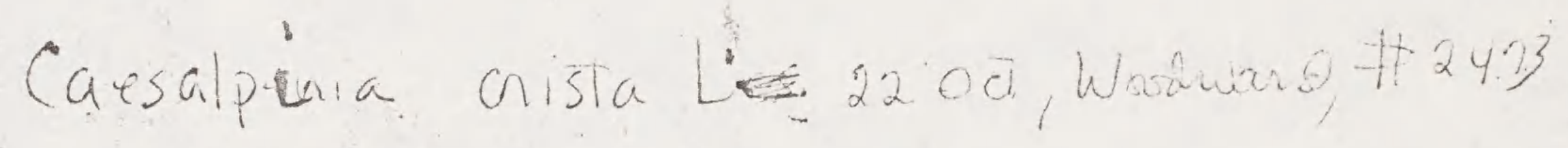

Guettada specioca L. a 22 Od, Lowerdiano He 2476

Porkulara samoaens is \&u. Poella 2524 , \#2410 bourua 